\title{
A new pathway of preparation and refined structure of $\left(\mathrm{NH}_{4}\right)_{2}\left[\mathrm{FeCl}_{5}\left(\mathrm{H}_{2} \mathrm{O}\right)\right]$
}

\author{
Darina Lacková, Iveta Ondrejkovičová and Marián Koman \\ Institute of Inorganic Chemistry, Technology and Materials, Faculty of Chemical and Food Technology, \\ Slovak University of Technology, Radlinského 9, 81237 Bratislava, Slovakia \\ iveta.ondrejkovicova@stuba.sk
}

\begin{abstract}
The title compound, $\left(\mathrm{NH}_{4}\right)_{2}\left[\mathrm{FeCl}_{5} \mathrm{H}_{2} \mathrm{O}\right]$ has been prepared by reaction between iron(III) chloride and ammonium chloride which was formed by hydrolysis of isonicotinamide or thionicotinamide in ethanol. The characterization was based on elemental analysis and infrared spectra. The crystal structure of the title compound has been refined by single crystal X-ray diffraction method at $293 \mathrm{~K}$. Crystals are orthorhombic, Pnma, with unit cell parameters: $a=13.760(1) \AA, b=9.960$ (1) $\AA, c=7.060$ (1) $\AA, Z=4$ and $R=3.5 \%$. The iron(III) atom in $\left[\mathrm{FeCl}_{5}\left(\mathrm{H}_{2} \mathrm{O}\right)\right]^{2-}$ ion is approximately octahedrally coordinated by five $\mathrm{Cl}$ atoms and one $\mathrm{O}$ atom of $\mathrm{H}_{2} \mathrm{O}$ molecule. This distortion is caused by the extensively hydrogen-bonded lattice. Structural parameters and IR spectra of similar compounds are compared and discussed.
\end{abstract}

Keywords: ammonium salt, aqua-pentachloroferrate(III), crystal structure, iron, IR-spectrum

\section{Introduction}

The title compound is a member of the series of iron(III) compounds of the general formula $\mathrm{A}_{2}\left[\mathrm{FeX}_{5}\left(\mathrm{H}_{2} \mathrm{O}\right)\right]$, where $\mathrm{A}$ is an alkali metal, ammonium or oxonium ion, and $\mathrm{X}$ is halide. Their crystallographic and magnetic properties were previously reviewed (Carlin and Palacio 1985). These compounds have been easily prepared from aqueous solutions containing $\mathrm{ACl}$ or $\mathrm{ABr}$ and appropriate ferric halide, and in several cases also HX. Another compounds which contain $\left[\mathrm{FeCl}_{5}\left(\mathrm{H}_{2} \mathrm{O}\right]^{2-}\right.$ anions and organic cations such as are $\mathrm{H}_{4}(\mathrm{cyclam})^{4+}$, $\left(\mathrm{enH}_{2}\right)^{2+}$ and $\left(\text { dienH}_{3}\right)^{3+}$ have been recently prepared and characterized (Subramanian 1993, James 2001, 2007).

The crystals of $\left(\mathrm{NH}_{4}\right)_{2}\left[\mathrm{FeCl}_{5}\left(\mathrm{H}_{2} \mathrm{O}\right)\right]$ have been usually prepared by slow evaporation of aqueous solutions containing a (1-2): 1 molar mix of $\mathrm{NH}_{4} \mathrm{Cl}$ and $\mathrm{FeCl}_{3} \cdot 6 \mathrm{H}_{2} \mathrm{O}$ (Sharma 1974, Figgis 1978, McElearney 1978, Partiti 1985). This compound was also obtained from hydrochloric acid solutions (Attenborough 1997).

This paper is a continuation of our previously reported studies on spectral and structural properties of iron complexes with derivatives of pyridine (Ondrejkovičová et al. 2008, 2009; Štefániková et al. 2008). Here we describe a new pathway of preparation of the title compound and its structural data are compared with published ones.

\section{Experimental}

\section{Chemicals and synthesis}

All chemicals were purchased commercially and used without further purification. $96 \%$ vol. ethanol was used as a solvent.
The title compound was prepared according following procedure. To an ethanol solution $(30 \mathrm{ml})$ of isonicotinamide, inia $(1.84 \mathrm{~g}, 0.015 \mathrm{~mol})$ was added conc. $\mathrm{HCl}(1.3 \mathrm{ml}, 0.015 \mathrm{~mol})$ and a solution which was prepared from $\mathrm{FeCl}_{3} \cdot 6 \mathrm{H}_{2} \mathrm{O}(4.2 \mathrm{~g}$, $0.015 \mathrm{~mol})$ and ethanol $(135 \mathrm{ml})$. The reaction mixture was stirred for 15 minutes and then left to stand at room temperature. After 3 days, a small amount of precipitated $[i n i a \mathrm{H}] \mathrm{Cl}$ was filtered out. Orange crystals of the title compound were obtained from the light orange filtrate after several weeks.

Anal. Calcd. for $[i n i a \mathrm{H}] \mathrm{Cl}(\%)$ : C, 45.44; H, 4.45; N, 17.66. Found: C, 45.70; H, 4.64; N, 17.95. Anal. Calcd. for $\left(\mathrm{NH}_{4}\right)_{2}\left[\mathrm{FeCl}_{5}\left(\mathrm{H}_{2} \mathrm{O}\right)\right](\%)$ : $\mathrm{H}, 3.48 ; \mathrm{N}$, 9.74. Found: H, 3.52; N, 9.44.

The title compound was also obtained when thionicotinamide (tnia) instead of inia was used. There $[$ tnia $\mathrm{H}] \mathrm{Cl}$ was isolated as a by product. Anal. Calcd. for $[$ tnia $\mathrm{H}] \mathrm{Cl}(\%)$ : C, 41.26; H, 4.04; N, 16.04 . Found: C, 40.76; H, 4.06; N, 15.72.

\section{X-ray Crystallography}

Intensity data for the title compound was collected using a Siemens P4 diffractometer with graphite monochromated MoK $\alpha$ radiation (Siemens 1990). The diffraction intensities were corrected for Lorentz and polarization effects with XSCANS (Siemens 1994). Absorption correction was applied using the program XEMP (Sheldrick 1990). The structure was solved by direct methods using the program SHELXS-86 (Sheldrick 1985) and refined by the full-matrix least-squares method on all $F^{2}$ data using the program SHELXL-97 (Sheldrick 2008). Geometrical analysis was performed using SHELXL-97. 
Tab. 1. Crystal data and structure refinement for $\left(\mathrm{NH}_{4}\right)_{2}\left[\mathrm{FeCl}_{5}\left(\mathrm{H}_{2} \mathrm{O}\right)\right]$.

\begin{tabular}{ll}
\hline Chemical formula & $\mathrm{H}_{10} \mathrm{Cl}_{5} \mathrm{FeN}_{2} \mathrm{O}$ \\
$M_{\mathrm{r}}$ & 287.20 \\
Crystal system, space group & orthorhombic, Pnma \\
Temperature (K) & $293(2)$ \\
$a, b, c(\AA)$ & $13.760(1), 9.960(1), 7.060(1)$ \\
$V\left(\AA^{3}\right)$ & $967.6(2)$ \\
$Z$ & 4 \\
Radiation type & $\mathrm{MoK} K_{\alpha}$ \\
Crystal size $(\mathrm{mm})$ & $0.10 \times 0.15 \times 0.20$ \\
Diffractometer & $\mathrm{Siemens} \mathrm{P} 4$ \\
Absorption correction & $\psi-\mathrm{scan} ; \mathrm{XEMP}$ \\
{$[I>2 \sigma(I)]$ reflections } & $1337 ; 965 ; 640$ \\
$R_{\text {int }}$ & 0.037 \\
$R\left[F^{2}>2 \sigma\left(F^{2}\right)\right], \omega R\left(F^{2}\right), S$ & $0.035 ; 0.066 ; 0.969$ \\
No. of parameters & 65 \\
$\left.\Delta\rangle_{\max }, \Delta\right\rangle_{\text {min }}\left(\mathrm{e} \AA^{-3}\right)$ & $0.35 /-0.391$ \\
\hline
\end{tabular}

The structure was drawn by ORTEP-3 (Farrugia 1997) and Mercury (Macrae 2006) software. The Single Crystal Suite WINGX was used as an integrated system for all the crystallographic programs and as the software for preparing the material for publication (Farrugia 1999).

All non-hydrogen atoms of the title compound were refined anisotropically as independent atoms.
Hydrogen atoms of water molecule were localized on a difference Fourier map. The hydrogen atoms of $\mathrm{NH}_{4}{ }^{+}$ion were recalculated into idealized positions (riding model).

\section{Other physical measurements}

Elemental analyses (carbon, hydrogen and nitrogen) were carried out by means of a Flash EA 1112 analyzer. The infrared spectra $\left(4000-100 \mathrm{~cm}^{-1}\right)$ were measured in solid state by $\mathrm{KBr}$ technique and recorded on Nicolet 5700 FTIR spectrophotometer.

\section{Results and discussion}

During attempts to prepare iron complexes with isonicotinamidium $\left(\right.$ inia $\left.^{+}\right)$and thionicotinamidium $(\text { tnia } \mathrm{H})^{+}$, respectively, there was observed hydrolysis of appropriate amides. It is known that the amides hydrolyze under both acidic and alkaline conditions. If amides of nicotinic acid are heated with a dilute hydrochloric acid, nicotinic acid is formed together with ammonium chloride (Jelinek and Urwin 1953). Hydrolysis of amides, e.g. nicotinamide takes place also in biosystems (Smith et al. 2012). In our case, ammonium chloride which was formed by hydrolysis of inia or tnia, reacted with iron(III) chloride and so $\left(\mathrm{NH}_{4}\right)_{2}\left[\mathrm{FeCl}_{5}\left(\mathrm{H}_{2} \mathrm{O}\right)\right]$ was formed. The reaction took place under ambient conditions in ethanol which contains about $4 \%$ vol. of water.

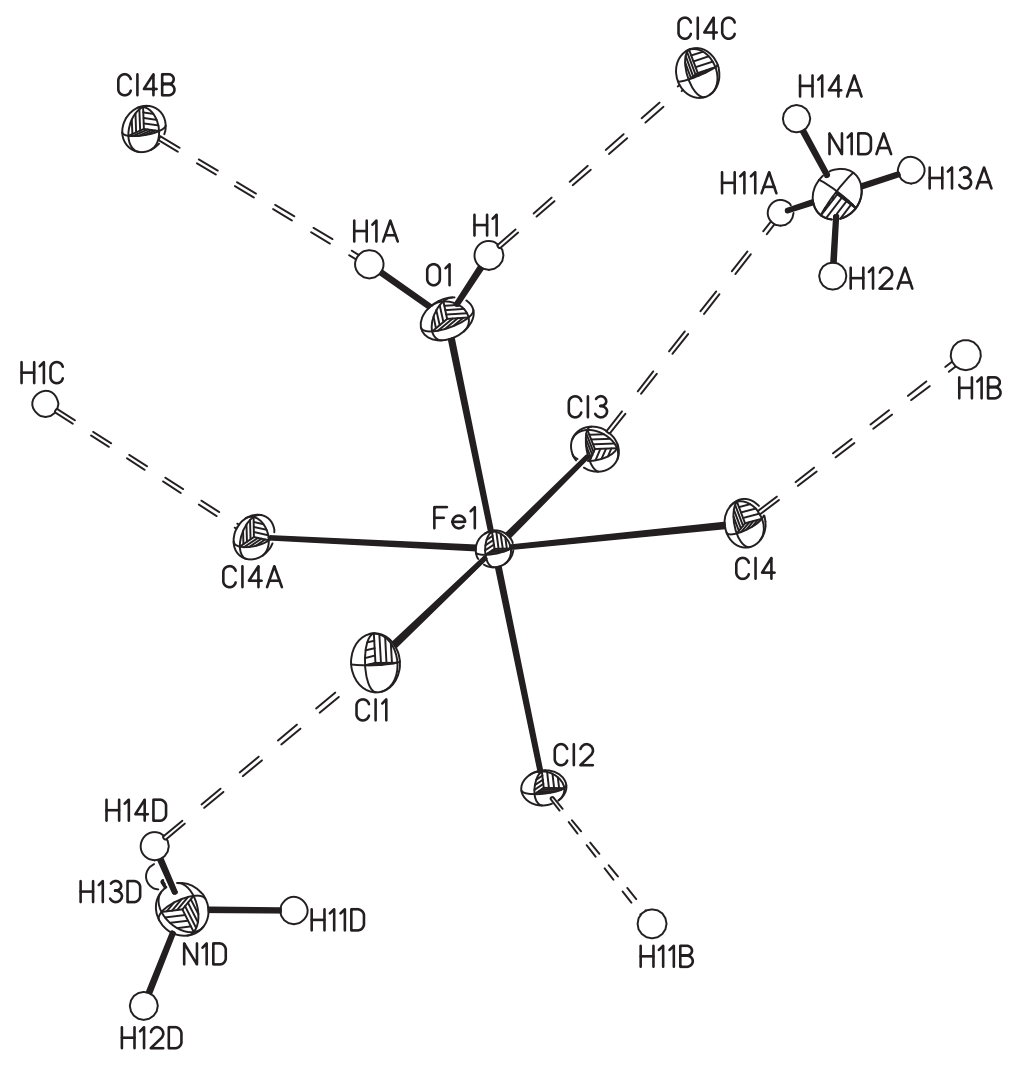

Fig. 1. The system of hydrogen bonds in crystal structure of $\left(\mathrm{NH}_{4}\right)_{2}\left[\mathrm{FeCl}_{5}\left(\mathrm{H}_{2} \mathrm{O}\right)\right]$. 
Tab. 2. Selected bond lengths $(\AA)$ and angles $\left(^{\circ}\right)$ for $\left(\mathrm{NH}_{4}\right)_{2}\left[\mathrm{FeCl}_{5}\left(\mathrm{H}_{2} \mathrm{O}\right)\right]$.

\begin{tabular}{lllclc}
\hline $\mathrm{Fe}-\mathrm{Cl}(1)$ & $2.396(2)$ & $\mathrm{Cl}(1)-\mathrm{Fe}-\mathrm{Cl}(2)$ & $92.22(6)$ & $\mathrm{Cl}(2)-\mathrm{Fe}-\mathrm{O}$ & $180.0(2)$ \\
$\mathrm{Fe}-\mathrm{Cl}(2)$ & $2.333(2)$ & $\mathrm{Cl}(1)-\mathrm{Fe}-\mathrm{Cl}(3)$ & $179.24(7)$ & $\mathrm{Cl}(3)-\mathrm{Fe}-\mathrm{Cl}(4)$ & $90.49(4)$ \\
$\mathrm{Fe}-\mathrm{Cl}(3)$ & $2.363(2)$ & $\mathrm{Cl}(1)-\mathrm{Fe}-\mathrm{Cl}(4)$ & $89.45(4)$ & $\mathrm{Cl}(3)-\mathrm{Fe}-\mathrm{O}$ & $89.4(2)$ \\
$\mathrm{Fe}-\mathrm{Cl}(4)$ & $2.390(1)$ & $\mathrm{Cl}(1)-\mathrm{Fe}-\mathrm{O}$ & $89.8(2)$ & $\mathrm{Cl}(4)-\mathrm{Fe}-\mathrm{O}$ & $85.59(4)$ \\
$\mathrm{Fe}-\mathrm{Cl}(4 \mathrm{~A})$ & $2.390(1)$ & $\mathrm{Cl}(2)-\mathrm{Fe}-\mathrm{Cl}(3)$ & $90.54(6)$ & $\mathrm{Cl}(4)-\mathrm{Fe}-\mathrm{Cl}(4 \mathrm{~A})$ & 171.12 \\
$\mathrm{Fe}-\mathrm{O}$ & $2.119(5)$ & $\mathrm{Cl}(2)-\mathrm{Fe}-\mathrm{Cl}(4)$ & $94.41(3)$ & $\mathrm{H}(1)-\mathrm{O}-\mathrm{H}(1 \mathrm{~A})$ & 89.29 \\
\hline
\end{tabular}

Tab. 3. Hydrogen bonds with $\mathrm{H} \cdots \mathrm{A}<r(\mathrm{~A})+2.000 \AA$ and $<\mathrm{D}-\mathrm{H} \cdots \mathrm{A}>110^{\circ}$ for $\left(\mathrm{NH}_{4}\right)_{2}\left[\mathrm{FeCl}_{5}\left(\mathrm{H}_{2} \mathrm{O}\right)\right]$.

\begin{tabular}{lccccl}
\hline D-H & $\mathbf{d}(\mathbf{D}-\mathbf{H})$ & $\mathbf{d}(\mathbf{H} \cdots \mathbf{A})$ & $<\mathbf{D}-\mathbf{H} \cdots \mathbf{A}$ & $\mathbf{d}(\mathbf{D} \cdots \mathbf{A})$ & $\mathbf{A}$ \\
\hline O1-H1 & 0.806 & 2.424 & 162.30 & 3.200 & $\mathrm{Cl} 4[-\mathrm{x},-\mathrm{y},-\mathrm{z}+1]$ \\
N1-H11 & 0.981 & 2.521 & 153.55 & 3.427 & $\mathrm{Cl} 2[-\mathrm{x}+1 / 2,-\mathrm{y}, \mathrm{z}+1 / 2]$ \\
N1-H11 & 0.981 & 2.790 & 114.30 & 3.316 & $\mathrm{Cl} 3[-\mathrm{x}+1 / 2,-\mathrm{y}, \mathrm{z}-1 / 2]$ \\
N1-H12 & 0.919 & 2.776 & 167.01 & 3.678 & $\mathrm{Cl} 4[-\mathrm{x}+1 / 2,-\mathrm{y}, \mathrm{z}-1 / 2]$ \\
N1-H13 & 0.755 & 2.780 & 168.99 & 3.524 & $\mathrm{Cl3}$ \\
N1-H14 & 0.891 & 2.833 & 125.71 & 3.430 & $\mathrm{Cl1}[-\mathrm{x}+1 / 2,-\mathrm{y}, \mathrm{z}+1 / 2]$ \\
N1-H14 & 0.891 & 2.907 & 133.51 & 3.579 & $\mathrm{Cl} 4[\mathrm{x}+1 / 2, \mathrm{y},-\mathrm{z}+1 / 2]$ \\
\hline
\end{tabular}

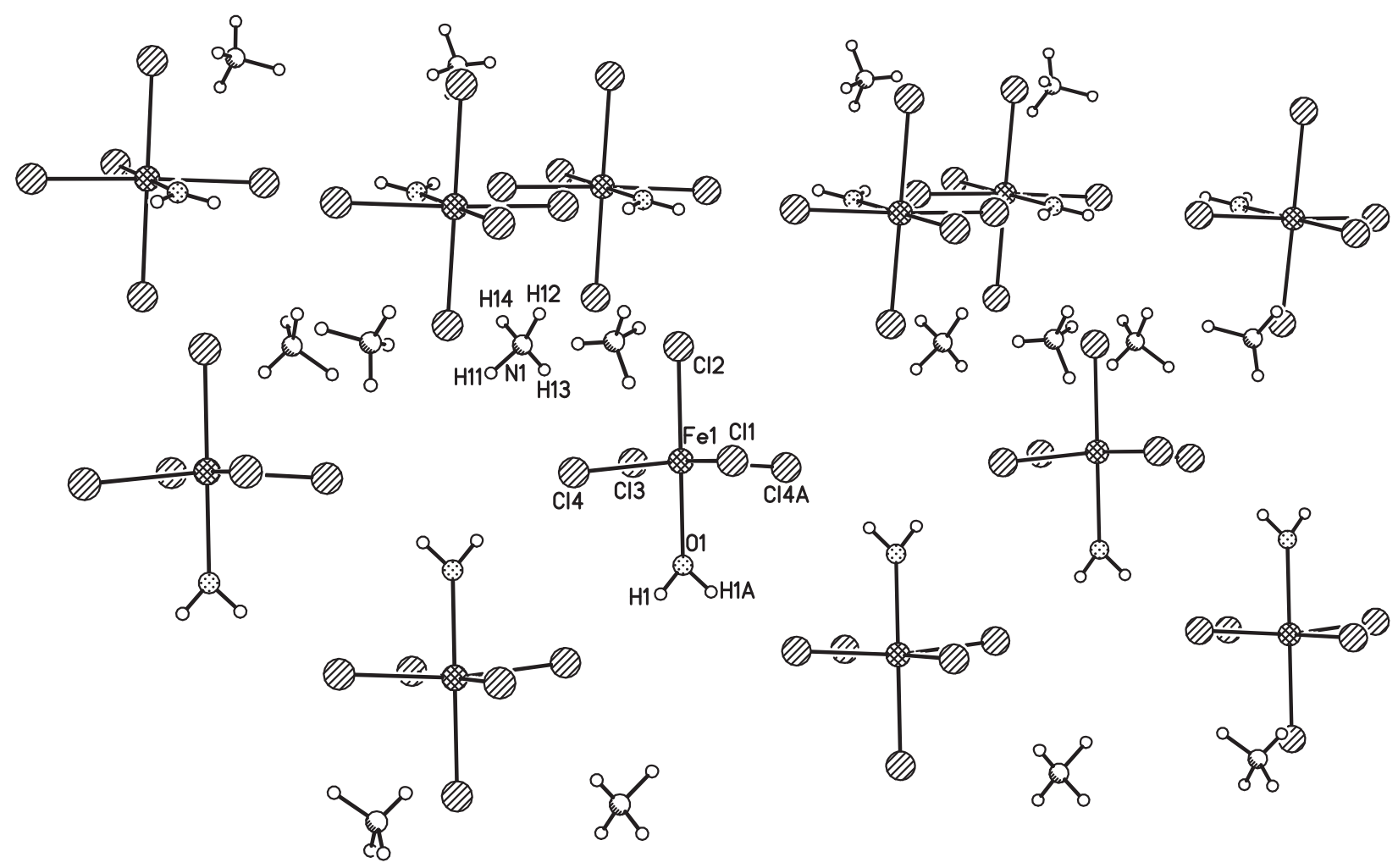

Fig. 2. Packing of molecules in crystal structure of $\left(\mathrm{NH}_{4}\right)_{2}\left[\mathrm{FeCl}_{5}\left(\mathrm{H}_{2} \mathrm{O}\right)\right]$.

The refinement structure of $\left(\mathrm{NH}_{4}\right)_{2}\left[\mathrm{FeCl}_{5}\left(\mathrm{H}_{2} \mathrm{O}\right)\right]$ confirmed the general features published earlier (Figgis 1978). Crystal data and conditions of data collection and refinement are reported in Table 1, bonds lengths and bonds angles are in Table 2 and hydrogen bonds parameters are in Table 3 .

The compound is built from one $\left[\mathrm{FeCl}_{5}\left(\mathrm{H}_{2} \mathrm{O}\right)\right]^{2-}$ and from two $\mathrm{NH}_{4}{ }^{+}$ions, which are held together by an ionic interaction and additional hydrogen bond inter- actions between coordinated $\mathrm{Cl}$ ligands and ammonia cations, $\mathrm{Cl} \cdots \mathrm{H}-\mathrm{N}$. Hydrogen bonds $\mathrm{Cl} \cdots \mathrm{H}-\mathrm{O}$ occur also between $\mathrm{H}_{2} \mathrm{O}$ and $\mathrm{Cl}$ ligands of neighbouring anions (Fig. 1 and Table 3). The system of hydrogen bonds is illustrated in Fig. 1. Packing of the molecules in crystal structure is shown in Fig. 2.

The iron(III) atom in $\left[\mathrm{FeCl}_{5}\left(\mathrm{H}_{2} \mathrm{O}\right)\right]^{2-}$ ion is in an approximately octahedral ligand environment formed by five $\mathrm{Cl}$ atoms and one molecule of water. This 
Tab. 4. Comparison of IR spectra data for $\mathrm{A}_{2}\left[\mathrm{FeCl}_{5}\left(\mathrm{H}_{2} \mathrm{O}\right)\right]\left(\mathrm{A}^{+}=\mathrm{NH}_{4}^{+}, \mathrm{K}^{+}, \mathrm{Rb}^{+}, \mathrm{Cs}^{+}\right)$.

\begin{tabular}{lcccc}
\hline $\begin{array}{l}\text { Vibration } \\
\left(\mathrm{cm}^{-1}\right)\end{array}$ & $\left(\mathrm{NH}_{4}\right)_{2}\left[\mathrm{FeCl}_{5}\left(\mathrm{H}_{2} \mathrm{O}\right)\right]^{\mathrm{a}}$ & $\mathrm{K}_{2}\left[\mathrm{FeCl}_{5}\left(\mathrm{H}_{2} \mathrm{O}\right)\right]^{\mathrm{b}}$ & $\mathrm{Rb}_{2}\left[\mathrm{FeCl}_{5}\left(\mathrm{H}_{2} \mathrm{O}\right)\right]^{\mathrm{b}}$ & $\mathrm{Cs}_{2}\left[\mathrm{FeCl}_{5}\left(\mathrm{H}_{2} \mathrm{O}\right)\right]^{\mathrm{b}}$ \\
\hline$\gamma\left(\mathrm{NH}_{4}^{+}\right)$ & 1390 & - & - & - \\
$v\left(\mathrm{NH}_{4}^{+}\right)$ & 3184 & - & 1584 & 1593 \\
$\sigma(\mathrm{HOH})$ & 1582 & 1585 & 3391 & 3389 \\
$\mathrm{v}_{\mathrm{s}}(\mathrm{OH})$ & 3388 & 3369 & 285,270 & not given \\
$\sigma(\mathrm{Fe}-\mathrm{Cl})$ & 279 & 285,271 & 371 & not given \\
$\mathrm{v}(\mathrm{Fe}-\mathrm{O})$ & 436,349 & 376 & & \\
\hline
\end{tabular}

athis work; 'Piszczek 2003; Nakamoto 2009.

distortion is caused by the extensively hydrogenbonded lattice. The Fe-Cl bond (2.333(2) A) which is trans to the water molecule, is evidently shorter than other four $\mathrm{Fe}-\mathrm{Cl}$ distances (their average is $2.385 \AA$ ), presumably as a manifestation of trans influence (Table 2). The angles in the anion are very close to the published data (Figgis 1978).

This study is in a good agreement with the earlier X-ray crystallographic reports for $\mathrm{A}_{2}\left[\mathrm{FeCl}_{5}\left(\mathrm{H}_{2} \mathrm{O}\right)\right]$, where $\mathrm{A}^{+}$is $\mathrm{NH}_{4}^{+}, \mathrm{K}^{+}, \mathrm{Cs}^{+}, \mathrm{Rb}^{+}$and $\mathrm{H}_{3} \mathrm{O}^{+}$(Figgis 1978 , McElearney 1978, O’Connor 1979, Søtofte 1981). When $\mathrm{A}^{+}$cation is replaced with the organic cation such as $\left(\mathrm{H}_{4}(\text { cyclam })^{4+},\left(\mathrm{enH}_{2}\right)^{2+}\right.$ or $\left.\left(\operatorname{dienH}_{3}\right)^{3+}\right)$, some quite remarkable perturbations from the octahedron were observed (Subramanian 1993, James 2007).

Comparison of the important infrared spectral data for $\mathrm{A}_{2}\left[\mathrm{FeCl}_{5}\left(\mathrm{H}_{2} \mathrm{O}\right)\right]$, where $\mathrm{A}^{+}$is $\mathrm{NH}_{4}{ }^{+}, \mathrm{K}^{+}, \mathrm{Rb}^{+}$ or $\mathrm{Cs}^{+}$are reported in Table 4 . The most intense bands in the spectrum are at 3184 and $1390 \mathrm{~cm}^{-1}$. These bands can be assigned to $\mathrm{NH}_{4}^{+}$vibrations (Nakamoto 2009). The $\delta(\mathrm{HOH})$ and $v_{\mathrm{s}}(\mathrm{OH})$ bands which occur at 1582 and $3388 \mathrm{~cm}^{-1}$, respectively clearly confirm the presence of water molecule in the anion (Piszczek 2003). Other bands at 436 and $349 \mathrm{~cm}^{-1}$ confirm the bond formation between iron and oxygen atoms. The peak at $279 \mathrm{~cm}^{-1}$ is attributed to the $\delta(\mathrm{Fe}-\mathrm{Cl})$, what is also in a good agreement with the literature data for the similar compounds (Piszczek 2003; Nakamoto 2009).

\section{Acknowledgement}

This work was supported by courtesy of the Slovak Grant Agency (VEGA 1/0056/13 and APVV-001411).

\section{References}

Attenborough M, Hall I, Nikolov O, Brown SR, (1997) Hyperfine Interactions 108: 435-442.

Carlin RL, Palacio F (1985) Coord. Chem. Rev. 65: 141-165.

Farrugia LJ (1997) J. Appl. Cryst 30: 565-566.

Farrugia LJ (1999) J. Appl. Cryst 32: 837-838.
Figgis BN, Raston CL, Sharma RP, White AH (1978) Aust. J. Chem. 31: 2717-2720.

James BD, Bakalova M, Liesegang J, Feiff WM, Skelton BW, White AH (2001) Inorg. Chem. 40: 4617-4622.

James BD, Mrozinski J, Klak J, Skelton BW, White AH, (2007) Z. Anorg. Allg. Chem. 663: 2683-2688.

James BD, Mrozinski J, Klak J, Skelton BW, White AH (2007) Z. Anorg. Allg. Chem. 633: 974-978.

Jellinek HHG, Urwin JR (1953) J. Phys. Chem. 57: 900-902.

Macrae CF, Edgington PR, McCabe P, Pidcock E, Shields GP, Taylor R, Towler M, van de Streek J (2006) J. Appl. Cryst 39: 453-457.

McElearney JN, Merchant S (1978) Inorg. Chem. 17: 1207-1215.

Nakamoto Kazuo (2009). In: Infrared and Raman Spectra of Inorganic and Coordination Compounds; Part A: Theory and Applications in Inorganic Chemistry, Wiley.

O'Conor ChJ, Deaver BS Jr, Sinn E (1979) J. Chem. Phys. 70: 5161-5167.

Ondrejkovičová I, Galková S, Mrozinski J, Kłak J, Lis T, Olejnik Z (2008) Inorg. Chim. Acta 361: 2483-2490.

Ondrejkovičová I, Wrzecion M, Nahorska M, Mrozinski J (2009) Polish J. Chem. 83: 1547-1553.

Partiti CSM, Piccini A, Rechenberg HR (1985) Solid State Commun. 56: 687-691.

Piszczek P, Grodzicki A, Engelen B (2003) J. Mol. Struct. 646: 45-54.

Sharma SK, Pandya DK (1974) J. Inorg. Nucl. Chem. 36: 1165-1166.

Sheldrick GM (1990) Acta Cryst. A46: 467-473.

Sheldrick GM (1985) SHELXS-86. In: Sheldrick, GM, Krueger R, Goddard R (Eds) Crystallographic Computing 3, Oxford University Press, 175.

Sheldrick GM (2008) Acta Cryst. A64: 112-122.

Siemens (1990) XEMP. Version 4.2, Siemens Analytical X-ray Instruments Inc., Madison, Wisconsin, USA.

Siemens (1994) Siemens Analytical X-ray Instruments Inc., Madison, Wisconsin, USA.

Smith BC, Anderson MA, Hoadley KA, Keck JL, Cleland WW, Denu JM (2012) Biochemistry 51: 243-256.

Søtofte I, Nielsen K (1981) Acta Chem. Scand. A 35: 821-822.

Subramanian S, Zaworotko MJ (1993) Can. J. Chem. 71: 433-440.

Štefánková S, Ondrejkovičová I, Koman M, Lis T, Mrozinski J, Wrzecion (2008) J. Coord. Chem. 61: 3895-3903. 